\title{
Brief communication: Getting Greenland's glaciers right - a new data set of all official Greenlandic glacier names
}

\author{
A. A. Bjørk ${ }^{1}$, L. M. Kruse ${ }^{2}$, and P. B. Michaelsen ${ }^{3}$ \\ ${ }^{1}$ Centre for GeoGenetics, Natural History Museum of Denmark, University of Copenhagen, Copenhagen, Denmark \\ ${ }^{2}$ Oqaasileriffik - The Greenland Language Secretariat, Ministry of Culture, Education, Research and Church, \\ Nuuk, Greenland \\ ${ }^{3}$ Danish Geodata Agency, Danish Ministry of the Environment, Copenhagen, Denmark \\ Correspondence to: A. A. Bjørk (andersb@snm.ku.dk)
}

Received: 11 February 2015 - Published in The Cryosphere Discuss.: 12 March 2015

Revised: 28 August 2015 - Accepted: 3 November 2015 - Published: 1 December 2015

\begin{abstract}
Place names in Greenland can be difficult to get right, as they are a mix of Greenlandic, Danish, and other foreign languages. In addition, orthographies have changed over time. With this new data set, we give the researcher working with Greenlandic glaciers the proper tool to find the correct name for glaciers and ice caps in Greenland and to locate glaciers described in the historic literature with the old Greenlandic orthography. The data set contains information on the names of 733 glaciers, 285 originating from the Greenland Ice Sheet (GrIS) and 448 from local glaciers and ice caps (LGICs).
\end{abstract}

\section{Why place names matter}

It goes without saying that referring to a geographical feature with a consistent name saves both the reader and the author a lot of trouble. However, problems may arise when there is no consensus as to which feature is being referred to or when the name changed. In Greenland, history has not been kind to the researcher who wishes to get the place names right. The written Greenlandic language has undergone changes since the first expeditions there, and names have changed over time. Furthermore, the languages spoken on the east and west coasts of Greenland also differ, causing further dissimilarities in the names. Therefore, it can be quite a challenge to use the correct place name in Greenland. There are already databases of geographic place names available, such as the US National Geospatial-Intelligence Agency GEOnet Names Server, but it has not been updated recently and contains er- rors and place names in the old Greenlandic orthography. While many researchers have gone to great lengths to get glacier names right (Higgins, 2010; Laursen, 1972; Rignot and Mouginot, 2012; Weidick, 1995), until now no complete list of official glacier names has been presented to the public. It is with this predicament in mind that we wish to share with the cryospheric community this data set of official names of all Greenlandic glaciers. Furthermore, we match the glacier names data set with the Randolph Glacier Inventory (GRI), the most complete glacier inventory available (Pfeffer et al., 2014; Rastner et al., 2012).

\section{A brief history of Greenlandic place names}

The official authority of place names in Greenland is Nunat Aqqinik Aalajangiisartut (NAA) (http://www.oqaasileriffik. gl) and the Danish Geodata Agency (GDA) (www.gst.dk), formerly the Danish Geodetic Institute. These have been well aware of the problems that may arise from differing place names and have initiated a formalization of all Greenlandic place names. This is no easy task in a country of Greenland's size, where humans have lived and traveled for centuries and have named features in the landscape. In addition to names already listed in the official database, names have also been collected by the GDA and later the NNA from maps, historic literature, and oral accounts.

Traditionally, Greenlandic place names have been more of a description of the place than a name in the conventional format. This is also the case with many glacier names; however, no complete translation exists (Geodatastyrelsen, 
2013). Danish or foreign names were often given to the glaciers during expeditions, but these are rarely descriptive of the glacier. Instead, the glacier names were often given to please funders, family, colleagues, and celebrities.

Registration of place names in Greenland became formalized in 1934 when the Greenland Place Names Committee was formed in Denmark (Kleivan, 1990). Efforts to formalize the place names were made during the creation of a large map series of the entire coastline. During this process, a representative from the then Danish Geodetic Institute would travel the coast and record all known names with the assistance of locals. All sorts of features were recorded, and the geographic location was pinned down on the map. The place names were thus based on communication with the locals and the quality of existing maps. This record, along with names from previously published maps that passed the board of the Greenland Place Names Committee, became part of the official list of recognized place names. This database, known as the "Berthelsen List", consisted of more than 25000 entries and was known to contain errors and discrepancies, such as double entries and wrong coordinates.

In 1973, Greenland underwent language reform and the orthography was changed. In 2001, the NNA implemented the new Danish way of spelling "glacier" (gletsjer). As an example, the large marine-terminating glacier, Kangerlussuaq Gletsjer, on the southeast coast of Greenland (Wager et al., 1937) was changed from Kangerdlugssuaq Gletscher to Kangerlussuaq Gletscher to Kangerlussuaq Gletsjer in the process. However, the pre-1973 orthography is most often used in the scientific literature (Bevan et al., 2012; Joughin et al., 2008; Khan et al., 2014).

In 1984, the responsibility for Greenlandic place names was transferred to the Greenland Home Rule and NNA. In 1996, single authorization of place names was introduced in Greenland, allowing only one official name, which is the Greenlandic name where applicable. Thus, Jakobshavn Isbrce, Greenland's fastest outlet (Joughin et al., 2014), officially became Sermeq Kujalleq. Since then, more than 6000 additional names have been added. It is from this list of place names that all glacier names have been extracted. Furthermore, all glacier entries have subsequently gone through vigorous quality control: erasing double entries, replacing misplaced data points by manually checking all entries in the data set, and comparing their location with that of maps published by the GDA. Higgins (2010) contains a comprehensive history of Greenlandic place names, which also includes a long list of both official and unofficial place names in northeast Greenland.

\section{A new data set of Greenlandic glacier names}

The present data set is a compilation of the official Greenlandic names of 733 glaciers; 285 glaciers are outlets or passive margins from the Greenland Ice Sheet (GrIS), and
448 are local glaciers or ice caps (LGICs). The 448 LGICs represent $\sim 2.2 \%$ of the more than 20,000 Greenlandic LGICs represented in the RGI. However, the LGICs on this list account for $\sim 41 \%$ of the total area of Greenlandic LGICs in the RGI. Figure 1 provides geographic location for named GrIS glaciers and LGICs and presents an example of the information available in the database. The database contains the old and new Greenlandic spellings of glacier names, the foreign name if one exists, and the current official place name. The current official place name is the new Greenlandic name, and when no Greenlandic name exists, the official name is the foreign name, often with the Danish suffix for glacier: gletsjer. Many of the Danish glacier name

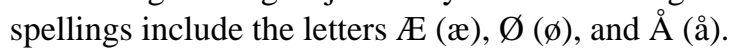

For each glacier presented in the database, information on the glacier's ID in the RGI (Pfeffer et al., 2014; Rastner et al., 2012) is available. The RGI ID was added because this is presently the most complete inventory of Greenlandic ice bodies. Furthermore, information regarding whether the name refers to a section or an outlet of the GrIS or is a LGIC is also available. Coordinates are given as latitude/longitude for the place name location and for the center coordinates of the glacier polygon in the RGI.

By examining the data set, one might notice that an intensively studied and unofficially named glacier is missing. This can be explained by the fact that the glacier name in question has yet to be recognized as having an official name, either because it has not been brought to the attention of the NNA or because it has been discarded by the authorities in the past. There are several examples of glaciers that have been widely studied and whose name may appear official but is not. A prominent example is the most studied local glacier in Greenland, which is known as the Mittivakkat Gletscher (Mernild et al., 2011). The name Mittivakkat (formerly spelled Midtluagkat) refers to the large nunatak on the glacier and was mapped in 1932, by the Seventh Thule Expedition led by the Danish explorer Knud Rasmussen (Rasmussen, 1933). Later, the glacier was given its unofficial name by researchers studying the glacier (Fristrup, 1960; Hasholt, 1976; Larsen, 1959). However, the name was never authorized by the proper authorities. There are many similar examples along the coast of Greenland. Another example is the large number of glaciers that were named by Norwegians in central east Greenland in the early 1930s. None of these names made it onto the official list, as they were regarded as politically motivated namings (Higgins, 2010), as Denmark and Norway were fighting over the right to east Greenland.

It should be noted that the database of official Greenlandic glacier names is not exhaustive nor finished; it is a work in progress, and the NAA is continuing the process of registering new and old place names. In connection with the publication of the present data set, we strongly urge the scientific community to send suggestions of old and already established glacier names that do not appear on the list. It is recommended that these should be sent along with the refer- 


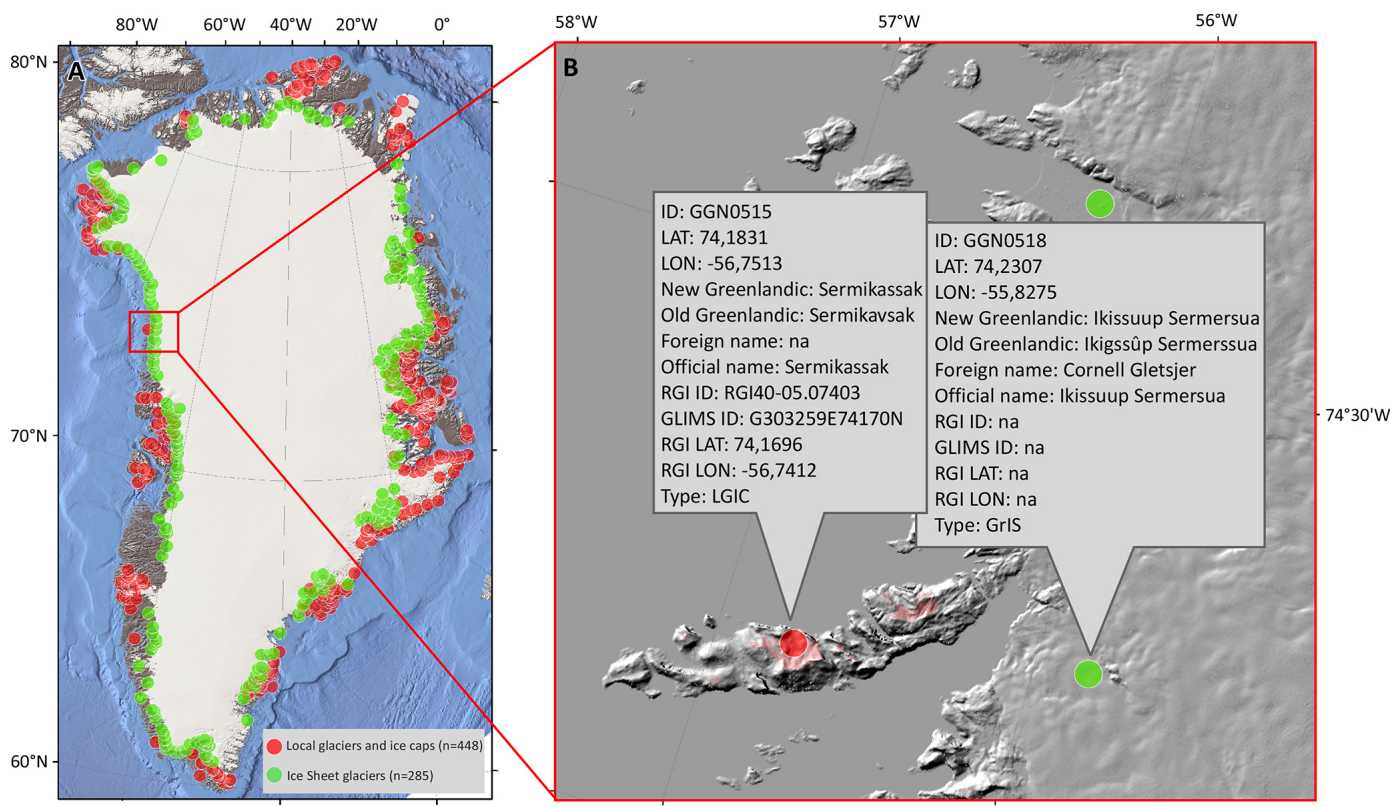

Figure 1. Distribution of official glacier names in Greenland and contents of new palace name data set. Local glaciers and ice caps (LGICs) are in green; glaciers from the Greenland Ice Sheet (GrIS) are in red. (a) The spatial concentration of glacier names is high in the populated areas and in areas that have been extensively explored - however, there are still fairly large stretches of coastline with no named glaciers (e.g., the southeast and north coasts). Background image: IBCAO ver3.0 (Jakobsson et al., 2012). (b) A zoom-in on the Melville Bay in northwest Greenland with examples of the contents of the new glacier name database. Background images are a GIMP hillshade (Howat et al., 2014).

ences in which the glacier name appears. We will then gather all these unofficial place names and submit a single application to the NNA to have the names considered. Once the glacier names are on the official list, they will appear, according to map scale and map purpose, on future official maps. This collaborative scientific effort will clarify the nomenclature of Greenlandic place names and greatly assist future work.

\section{Using this data set}

The data set presented is available online in a spreadsheet, as an ArcGIS shape file, and as a KML layer. The data set can be accessed at Figshare, where it will be updated and stored under a Creative Commons (CC0) license (http://dx.doi.org/10.6084/m9.figshare.1449148, http://figshare.com/articles/GreenlandGlacierNames_ GGNv01/1449148).

To avoid further confusion regarding the use of the correct names, we suggest that the official glacier name be used whenever referring to a Greenlandic glacier. However, as many glaciers have been studied in the past, but the literature refers only to the Danish/non-Greenlandic name, we suggest that both names are mentioned in cases where a glacier's unofficial foreign name has become widely accepted within the scientific community. When using this data set, please reference this publication.

\section{The Supplement related to this article is available online at doi:10.5194/tc-9-2215-2015-supplement.}

Acknowledgements. We wish to thank all the individuals and authorities who throughout the years have collected and maintained what has become this data set, as well as Hester Jiskoot and Jacob Yde, whose reviews greatly improved this paper. Furthermore we thank Andreas Sanimuinaq, Boas Nathanielsen, Domilia Kristiansen, Efraim Olsen, Hans Uitsatikitseq, Hjelmer Hammeken, Inukitsorsuaq Sadorana, Jakob Skade, Jakob Zeeb, Juliu J. Jørgen Jensen, Jaappili B. Ignatiussen, Kangaamiut Aviisiat, Karl Berthelsen, Lars B. Mikaelsen, Lars Jeremiassen, Lars Kilime, Levi Uitsatikitseq, Mamarut Kristiansen, Marius Nakinge, Morten Josvassen, Niels Fly, Nukappiannguaq Hendriksen, Odaaq Tivnaaq, Ole Mørch, Rasmus Ignatiussen, Siorantigut, Taliilannguaq Peary, and Ulrik Sanimuinnaq, who have all contributed to the compilation of alternative glacier names, and Martin Hvidberg (GST), Allen Pope and Kenneth Mankoff for valuable discussions and advice. This work is part of the "X_Centuries Project" funded by the Danish Council Research for Independent Research (FNU) (grant no. 0602-02526B).

Edited by: E. Larour 


\section{References}

Bevan, S. L., Luckman, A. J., and Murray, T.: Glacier dynamics over the last quarter of a century at Helheim, Kangerdlugssuaq and 14 other major Greenland outlet glaciers, The Cryosphere, 6, 923-937, doi:10.5194/tc-6-923-2012, 2012.

Fristrup, B.: Studies of four glaciers in Greenland, Danish J. Geogr., 59, 89-102, 1960.

Geodatastyrelsen: Den grønlandske Lods - Forklaringer til stednavne, Copenhagen, Denmark, 2013.

Hasholt, B.: Hydrology and transport of material in the Sermilik Area 1972, Danish J. Geogr., 75, 30-38, 1976.

Higgins, A. K.: Exploration history and place names of northern East Greenland, Geol. Surv. Denmark Greenl. Bull., 21, 368 pp., 2010.

Howat, I. M., Negrete, A., and Smith, B. E.: The Greenland Ice Mapping Project (GIMP) land classification and surface elevation data sets, The Cryosphere, 8, 1509-1518, doi:10.5194/tc-81509-2014, 2014.

Jakobsson, M., Mayer, L., Coakley, B., Dowdeswell, J. A., Forbes, S., Fridman, B., Hodnesdal, H., Noormets, R., Pedersen, R., Rebesco, M., Schenke, H., Zarayskaya, Y., Accettella, D., Armstrong, A., Anderson, R., Bienhoff, P., Camerlenghi, A., Church, I., Edwards, M., Gardner, J., Hall, J., Hell, B., Hestvik, O., Kristoffersen, Y., Marcussen, C., Mohammad, R., Mosher, D., Nghiem, S., Pedrosa, M., Travaglini, P., and Weatherall, P.: The international bathymetric chart of the Arctic Ocean (IBCAO) version 3.0, Geophys. Res. Lett., 39, 1-6, 2012.

Joughin, I., Howat, I. M., Alley, R. B., Ekstrom, G., Fahnestock, M., Moon, T., Nettles, M., Truffer, M., and Tsai, V. C.: Icefront variation and tidewater behavior on Helheim and Kangerdlugssuaq Glaciers, Greenland, J. Geophys. Res., 113, 1-11, doi:10.1029/2007JF000837, 2008.

Joughin, I., Smith, B. E., Shean, D. E., and Floricioiu, D.: Brief Communication: Further summer speedup of Jakobshavn Isbræ, The Cryosphere, 8, 209-214, doi:10.5194/tc-8-209-2014, 2014.

Khan, S., Kjeldsen, K. K., Kjær, K. H., Bevan, S. L., Luckman, A., Aschwanden, A., Bjørk, A. A., Korsgaard, N. J., Box, J. E., van den Broeke, M., van Dam, T. M., and Fitzner, A.: Glacier dynamics at Helheim and Kangerdlugssuaq glaciers, southeast Greenland, since the Little Ice Age, The Cryosphere, 8, 14971507, doi:10.5194/tc-8-1497-2014, 2014.
Kleivan, I.: Debate and linguistic usage in connection with double place-names in Greenland, in: Arctic Languages - An Awakening, edited by: Collins, D. R. F., UNESCO, Paris, 341-342, 1990.

Larsen, H. V.: Runoff studies from the Mitdluagkat Gletcher in SEGreenland during the late summer 1958, Danish J. Geogr., 58, 54-65, 1959.

Laursen, D.: The Place Names of North Greenland, Meddelelser om Grønl., 180, 1-443, 1972.

Mernild, S. H., Knudsen, N. T., Lipscomb, W. H., Yde, J. C., Malmros, J. K., Hasholt, B., and Jakobsen, B. H.: Increasing mass loss from Greenland's Mittivakkat Gletscher, The Cryosphere, 5, 341-348, doi:10.5194/tc-5-341-2011, 2011.

Pfeffer, W. T., Arendt, A. A., Bliss, A., Bolch, T., Cogley, J. G., Gardner, A. S., Hagen, J.-O., Hock, R., Kaser, G., Kienholz, C., Miles, E. S., Moholdt, G., Mölg, N., Paul, F., Radić, V., Rastner, P., Raup, B., Rich, J., and Sharp, M. J.: The Randolph Glacier Inventory: a globally complete inventory of glaciers, J. Glaciol., 60, 537-552, doi:10.3189/2014JoG13J176, 2014.

Rasmussen, K.: Explorations in Southeastern Greenland: Preliminary Report of the Sixth and Seventh Thule Expeditions, Geogr. Rev., 23, 385-393, 1933.

Rastner, P., Bolch, T., Mölg, N., Machguth, H., Le Bris, R., and Paul, F.: The first complete inventory of the local glaciers and ice caps on Greenland, The Cryosphere, 6, 1483-1495, doi:10.5194/tc-6-1483-2012, 2012.

Rignot, E. and Mouginot, J.: Ice flow in Greenland for the International Polar Year 2008-2009, Geophys. Res. Lett., 39, L11501, doi:10.1029/2012GL051634, 2012.

Wager, L., Deer, W., Wager, H., and Manley, G.: The Kangerdlugssuak Region of East Greenland, Geogr. J., 90, 393-421, doi:10.2307/1787969, 1937.

Weidick, A.: Satellite Image Atlas of Glaciers of the World Greenland, US Geological Survey professional paper 1386-C, US. Geological Survey, Washington, US, 1995. 